\title{
RELATION BETWEEN SERUM 25-HYDROXY-VITAMIN D LEVELS AND TSH RECEPTOR ANTIBODY SEROPOSITIVITY
}

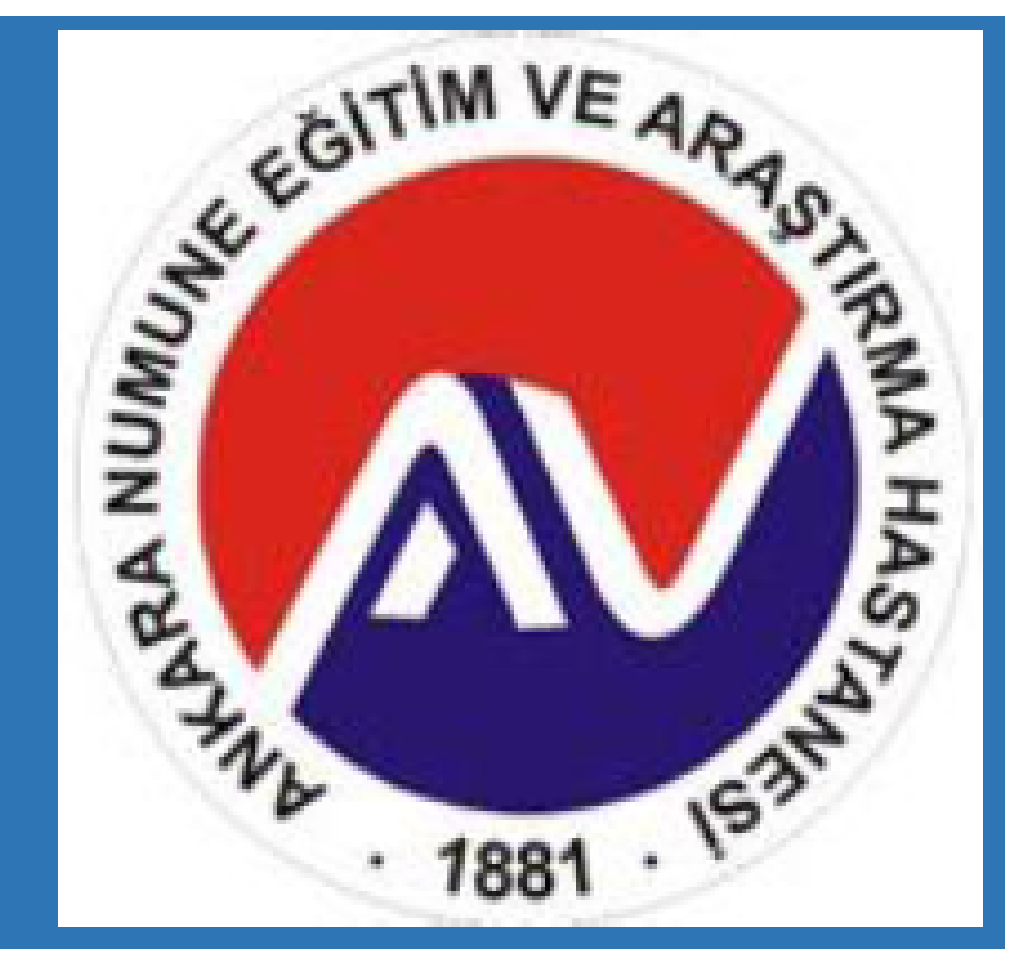

\section{Fatma Saglam¹, Derya Koseoglu1, Dilek Berker ${ }^{1}$, Serdar Guler ${ }^{1}$}

1: Ankara Numune Research and Training Hospital, Department of Endocrinology and Metabolism. Ankara-TURKEY.

\section{OBJECTIVE}

Vitamin $D$ is an immune-modulator that may play a role in thyroid related autoimmunity. But the relation between Vitamin D and Graves' disease (GD) is not well defined yet. The aim of this study was to investigate the association of 25hydroxy-vitamin D (25[OH]D) levels and TSH receptor antibody (TRab) levels in GD.

\section{METHOD}

A total of 429 GD patients were analyzed retrospectively. 122 of 429 patients had vitamin D levels were enrolled in this study. The levels of 25(OH)D and TRAb were examined. Vitamin D deficiency was defined as a 25(OH)D below $20 \mathrm{ng} / \mathrm{ml}$ and insufficiency as a $25(\mathrm{OH}) \mathrm{D}$ of $20-29 \mathrm{ng} / \mathrm{ml}$. Normal range was accepted as $30 \mathrm{ng} / \mathrm{ml}$ and above. TRAb negativity was defined as $0-13 \mathrm{U} / \mathrm{L}$ and positivity was defined as $14 \mathrm{U} / \mathrm{L}$ and above. Statistical analyses were conducted in SPSS (version 17.0). Chisquare and Pearson correlation tests were used and $\mathrm{P}<0.05$ were accepted as statistically significant.

\section{RESULTS}

Among 122 patients mean age was $42.9 \pm 14$ years of age. $72.1 \%$ of them $(n=88)$ were females and $27.9 \%(n=34)$ were males. TRAb seropositivity was found in $69.7 \%(n=85)$. TRAb titres' median was $16 \mathrm{U} / \mathrm{L}$ (minimum=0 and maximum=295 $\mathrm{U} / \mathrm{L})$. Vitamin D deficiency was detected in $83.6 \%(102 / 122)$ of the patients. Vitamin D insufficiency was found in $11.5 \%$ $(14 / 122)$ of the patients. Normal vitamin D levels were found in $4.9 \%(6 / 122)$ of the patients. Vitamin D deficiency was found as higher in TRAb-positive GD patients $(75.5 \%, 77 / 102)$ than that of TRAb-negative patients $(24.5 \%, 25 / 102)\left(X^{2}=12.176, d f=2\right.$, $\mathrm{p}=0.003$, Fisher's exact test) (Table 1 ).

Table 1. Vitamin D categories and its relation with TRAb seropositivities

\begin{tabular}{lcccc} 
& $\begin{array}{c}\text { Deficiency } \\
(\mathbf{n}=102)\end{array}$ & $\begin{array}{c}\text { Insufficiency } \\
(\mathbf{n}=14)\end{array}$ & $\begin{array}{c}\text { Normal } \\
(\mathbf{n}=6)\end{array}$ & $\begin{array}{c}\text { Total } \\
(\mathbf{n}=122)\end{array}$ \\
TRab & $\mathbf{n}(\%)$ & $\mathbf{n}(\%)$ & $\mathbf{n}(\%)$ & $\mathbf{n}(\%)$ \\
Positive & $77(75.5)$ & $7(50.0)$ & $1(16.7)$ & $85(69.7)$ \\
Negative & $25(24.5)$ & $7(50.0)$ & $5(83.3)$ & $37(30.3)$ \\
\hline
\end{tabular}

In terms of vitamin D insuffiency, however, there was no difference between TRAb-positive and negative GD patients $\left(X^{2}=4.004, d f=1, p=0.059\right.$, Fisher's exact test) (Table 2).

Table 2. Vitamin D deficiency and insufficiency in connection with TRAb seropositivity

\begin{tabular}{lccc} 
& $\begin{array}{c}\text { Deficiency } \\
(\mathbf{n}=102)\end{array}$ & $\begin{array}{c}\text { Insufficiency } \\
(\mathbf{n}=14)\end{array}$ & $\begin{array}{c}\text { Total } \\
(\mathbf{n}=116)\end{array}$ \\
TRab & $\mathbf{n}(\mathbf{\%})$ & $\mathbf{n}(\%)$ & $\mathbf{n}(\%)$ \\
Positive & $77(75.5)$ & $7(50.0)$ & $85(72.4)$ \\
Negative & $25(24.5)$ & $7(50.0)$ & $32(27.6)$ \\
\hline
\end{tabular}

There was also found a significant negative correlation between TRAb titres and vitamin D levels (Pearson's rho=0.193, $\mathrm{p}=0.033$ ) (Figure 1).

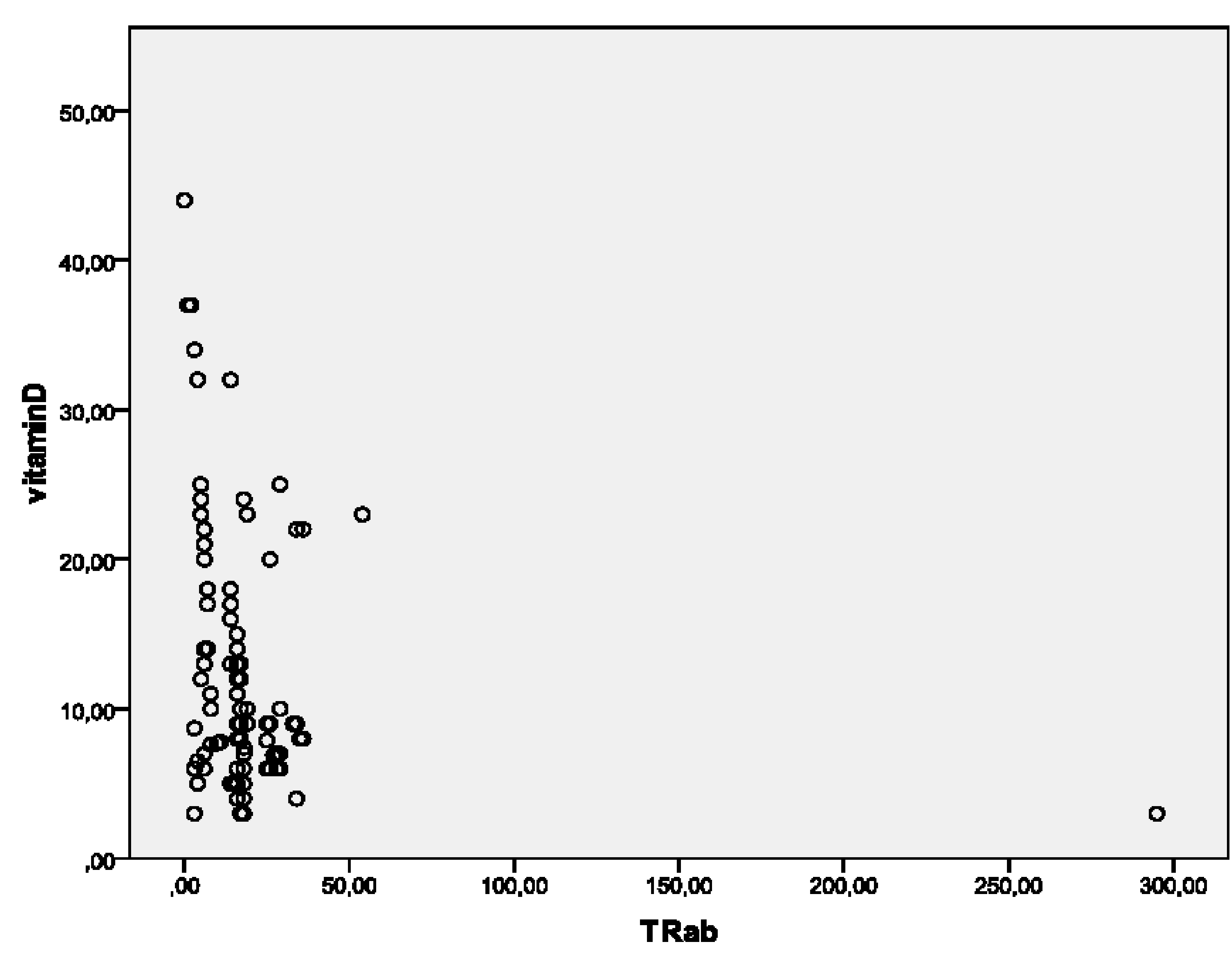

Figure 1. A significant negative correlation between vitamin D and TRab levels

\section{CONCLUSION}

Low vitamin D status is associated with increased TRAb seropositivity in GD. Further research is necessary to fully elucidate the importance of vitamin D in the case of GD. 